\title{
Evidence Summary: Enzymatic debridement for pressure injuries
}

Dec 2019

Author: Wound Healing and Management Unit, Curtin University (WHAM@Curtin)

For referencing Wound Healing and Management Unit. Evidence Summary: Enzymatic debridement for pressure injuries.

Wound Practice and Research 2020; 28(4):192-194.

DOI https://doi.org/10.33235/wpr.28.4.192-194

\section{CLINICAL QUESTION}

What is the best available evidence for enzymatic debridement to promote complete healing and/or improvement in wound bed condition in pressure injuries (PIs)?

\section{SUMMARY}

Evidence from three randomised controlled trials (RCTs), ${ }^{1-4}$ two ${ }^{1,4}$ of which were included in a network meta-analysis, ${ }^{5}$ provided Level 1 evidence supporting use of a collagenase to debride PIs to promote complete healing. ${ }^{1-5}$ Level $2^{6}$ and Level $3^{7,8}$ evidence suggested use of a collagenase to debride PIs was associated with superior improvements in the wound bed condition compared with sharp ${ }^{6}$ or autolytic debridement. ${ }^{7}$, 8 Level 1 evidence $^{9,10}$ found no difference between a collagenase and other types of enzymatic debridement for achieving PI healing. Expert opinion (Level 5) suggested that the urgency of debridement, ${ }^{11-15}$ vascularisation of the wound bed, ${ }^{16}$ type of non-vitalised tissue to be debrided, ${ }^{17}$ the patient's tolerance of the treatment, ${ }^{18,} 19$ and financial cost $^{1,3,20,21}$ are all considerations when selecting a method for debriding Pls. This evidence supported a Grade $B$ recommendation (a weak recommendation). ${ }^{22}$

\section{CLINICAL PRACTICE RECOMMENDATIONS}

Enzymatic debridement can be used to remove devitalised tissue from pressure injuries in the presence of adequate vascularisation and in the absence of a need for rapid removal of non-viable tissue (Grade B).

\section{SOURCES OF EVIDENCE}

This summary was conducted using methods published by the Joanna Briggs Institute. ${ }^{22-24}$ The summary is based on a literature search combining search terms related to $\mathrm{Pls}$ and enzymatic debridement. Searches were conducted in CINAHL, Medline, the Cochrane Library and Google Scholar for evidence published up to November 2019 in English. Levels of evidence for intervention studies are reported in the table below. $(1$ = high)

\section{BACKGROUND}

Debridement is the process of removing devitalized tissue (e.g. necrotic tissue or bacteria/biofilm) from the wound bed. One method of debriding a wound is enzymatic debridement-the use of exogenous enzymes that digest proteins (collagen and/or fibrin) in necrotic tissue. ${ }^{5}$ Enzymes used for debridement include general proteolytics (active against a broad range of protein matter), fibrinolytics (active against fibrin) and collagenases (selective action against collagen). ${ }^{19,28}$ Collagenase ointment appears to act on lower levels of necrotic tissue, working from the bottom of the wound bed up. ${ }^{25}$ Papain-based enzymatic debriding agents act from the top of the wound down, and act against all protein that contains cysteine,${ }^{17}$ working best in the presence of urea. ${ }^{17,25}$

\section{EVIDENCE}

Evidence from primarily pre-1980s studies reporting positive impact of enzymatic debridement for chronic wounds (some studies including PIs) is summarised in narrative in two systematic reviews. ${ }^{18,25}$ Both reviews ${ }^{18,25}$ reported primarily low level evidence at high risk of bias outlining the clinical benefits of enzymatic debriding agents, with some small studies offering favourable comparisons to placebo treatment. These studies provided early support for using enzymes to debride chronic wounds more slowly and with generally low levels of pain ${ }^{25}$ (both Level 1).

\begin{tabular}{|c|c|c|c|c|}
\hline Level 1 Evidence & $\begin{array}{l}\text { Level } 2 \\
\text { Evidence }\end{array}$ & $\begin{array}{l}\text { Level } 3 \\
\text { Evidence }\end{array}$ & $\begin{array}{l}\text { Level } 4 \\
\text { Evidence }\end{array}$ & Level 5 Evidence \\
\hline Experimental Designs & $\begin{array}{l}\text { Quasi-experimental } \\
\text { Designs }\end{array}$ & $\begin{array}{l}\text { Observational - } \\
\text { Analytic Designs }\end{array}$ & $\begin{array}{l}\text { Observational - } \\
\text { Descriptive Studies }\end{array}$ & $\begin{array}{l}\text { Expert Opinion/ } \\
\text { Bench Research }\end{array}$ \\
\hline 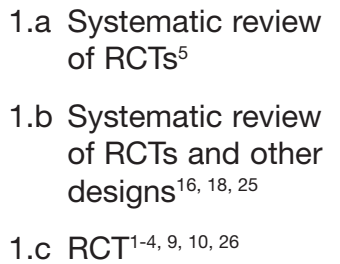 & $\begin{array}{l}\text { 2.d Pre-test - post- } \\
\text { test or historic } \\
\text { control study }{ }^{6,27}\end{array}$ & $\begin{array}{l}\text { 3.d Case - controlled } \\
\text { study }^{7,8}\end{array}$ & $\begin{array}{l}\text { Level 4.b Cross- } \\
\text { sectional study }{ }^{26}\end{array}$ & $\begin{array}{l}\text { 5.b Expert } \\
\text { consensus }{ }^{11-15} \\
\text { 5.c } \begin{array}{l}\text { Bench research/ } \\
\text { single expert } \\
\text { opinion }^{17,19,28,29}\end{array}\end{array}$ \\
\hline
\end{tabular}


Enzymatic debridement to promote complete healing

- A network meta-analysis of RCTs ${ }^{5}$ (two RCTs, ${ }^{1,4} n=61$ participants in total) showed collagenase ointment was associated with an increase in complete healing within up to 16 weeks compared with advanced wound dressing (risk ratio $[R R]=2.12,95 \%$ confidence interval $[\mathrm{Cl}] 1.06$ to 4.22), with 176 more Pls per 1,000 likely to heal. However, the studies were at high risk of bias and certainty in the result was low ${ }^{5}$ (Level 1).

- In an RCT at high risk of bias ( $n=27 \mathrm{PIs}),{ }^{2,3}$ collagenase ointment was associated with an increase in complete healing within 84 days compared with autolytic debridement using a hydrogel (collagenase $69 \%$ versus autolysis $21 \%$, $p=0.02),{ }^{2,3}$ as well as faster healing rates $^{2}$ (Level 1).

- An early $\mathrm{RCT}^{26}$ ( $\mathrm{n}=17 \mathrm{PIs}$ ) at high risk of bias reported a non-specific fibrinolytic (streptokinase/streptodornase) was associated with slower healing than autolytic debridement using a hydrogel, but the difference was not significant. In most countries, this treatment has been superseded by contemporary enzymatic debriding agents $^{26}$ (Level 1).

- In a cohort study at high risk of bias ( $\mathrm{n}=434 \mathrm{Pls}$ ), ${ }^{27}$ collagenase ointment was associated with statistically significantly higher rates of healing by 12 months compared with sharp debridement (collagenase $22 \%$ versus sharp debridement $11 \%$, hazard ratio $[\mathrm{HR}]=1.85,95 \% \mathrm{Cl} 1.28$ to $2.68, p=0.001)^{27}$ (Level 2). However, healing rates in both groups were low and may not be clinically significant.

\section{Enzymatic debridement to promote improvement in the} wound bed condition

- In a cohort study at low risk of bias $(n=114),{ }^{6}$ collagenase ointment was associated with significantly greater improvements in overall score $(p=0.022)$ and in necrotic tissue score $(p=0.0001)$ on the Bates-Jensen Wound Assessment Tool (BWAT) compared to wounds receiving sharp debridement. There was no significant difference in change in wound surface area between the two debridement methods. Both groups received concurrent negative pressure wound therapy ${ }^{6}$ (Level 2).

- In a case-controlled study at low risk of bias ( $\mathrm{n}=$ 557 PIs), collagenase ointment was associated with improved granulation by 12 months compared to autolytic debridement using medicinal honey (collagenase 100\% granulation versus honey $38 \%$, odds ratio $[\mathrm{OR}]=1.384$, $95 \% \mathrm{Cl} 1.057$ to $1.812, \mathrm{p}=0.018) .^{7}$ This finding was supported by an observational study at low risk of bias that reported treatment of Pls $(n=46,054)$ with collagenase ointment was associated with requiring fewer follow-up visits compared to medicinal honey, including lower rates of hospital readmission $(\mathrm{OR}=0.86,95 \% \mathrm{Cl}$ 0.80 to $0.94, p=0.0002)^{8}$ (both Level 3).

Comparisons between different types of enzymatic debridement

- Two RCTs, ${ }^{9,}, 10$ both at moderate risk of bias, showed no significant difference in healing outcome measures between collagenase ointment and debridement with papain-urea ( $\mathrm{n}=26 \mathrm{Pls})^{9}$ and debridement using a fibrinolytic $(\mathrm{n}=78 \mathrm{PIs})^{10}$ (both Level 1$)$.

\section{CONSIDERATIONS FOR USE}

The following points should be considered when performing enzymatic debridement:

- Adequate wound bed vascularity should be established before performing debridement ${ }^{16}$ (Level 1).

- In limbs/heels with poor vascularity or ischemia, dry stable eschar should usually be left undisturbed, except when infection is suspected. When infection is suspected, consult an appropriate medical practitioner ${ }^{11-16}$ (Leve/s 1 and 5).

- Enzymatic debridement is appropriate when the need to remove devitalised tissue is not clinically urgent. In the presence of extensive necrotic tissue, crepitus, flatulence or signs of advanced cellulitis or sepsis, more rapid methods of debridement (e.g. surgical/sharp debridement) should be performed ${ }^{11-15}$ (Level 5).

- Papain-urea could be selected when excessive necrotic tissue is present and collagenase could be selected for wound beds containing excessive fibrous tissue or mixed non-viable tissue ${ }^{17}$ (Level 5).

- Individuals may experience pressure injury pain and/or burning sensations from enzymatic debridement. Diluting the enzymatic agent in hydrogel might help reduce pain ${ }^{19}$ (Level 5) and maintain a moist healing environment ${ }^{18}$ (Level 1).

- Economic analyses 1, 3, 20, 21 suggest that enzymatic (collagenase) debridement is associated with lower financial costs than using sharp debridement, ${ }^{21}$ autolytic debridement with medicinal honey (although the difference was not statistically significant) ${ }^{20}$ or using an advanced wound dressing only. ${ }^{1,3}$

- Manufacturer instructions should always be followed, including when selecting a compatible wound dressing to apply $^{29}$ (Level 5).

\section{REFERENCES}

1. Muller E, van Leen MW, Bergemann R. Economic evaluation of collagenase-containing ointment and hydrocolloid dressing in the treatment of pressure ulcers. Pharmacoeconomics, 2001;19(12):1209-16.

2. Milne $\mathrm{CT}$, Ciccarelli $\mathrm{AO}$, Lassy M. A comparison of collagenase to hydrogel dressings in wound debridement. Wounds, 2010. Nov;22(11):270-4.

3. Waycaster C, Milne CT. Clinical and economic benefit of enzymatic debridement of pressure ulcers compared to autolytic debridement with a hydrogel dressing. J Med Econ, 2013. May 24;16(7):976-86.

4. Burgos A, Gimenez J, Moreno E, Lamberto E, Ultrera M, Urraca EM, Vélez FJ, López E, Martínez MA, Gómez MJ, García L. Cost, efficacy, efficiency and tolerability ofcollagenase ointment versus hydrocolloid occlusive dressing in the treatment ofpressure ulcers. Clin Drug Investig, 2000;19(5):357-65.

5. Westby MJ, Dumville JC, Soares MO, Stubbs N, Norman G. Dressings and topical agents for treating pressure ulcers. Cochrane Database Syst Rev, 2017(6):CD011947.

6. McCallon SK, Frilot C. A retrospective study of the effects of clostridial collagenase ointment and negative pressure wound therapy for the treatment of chronic pressure ulcers. Wounds, 2015;27(3):44-53.

7. Gilligan AM, Waycaster CR, Bizier R, Chu BC, Carter MJ, Fife CE. Comparative effectiveness of clostridial collagenase ointment to medicinal honey for treatment of pressure ulcers. Adv Wound Care, 2017;6(4):125-34.

8. Dreyfus J, Delhougne G, James R, Gayle J, Waycaster C. Clostridial collagenase ointment and medicinal honey utilization for pressure ulcers in US hospitals. Journal of Medical Economics, 2018;21(4):390-7. 
9. Alvarez OM, Fernandez-Obregon A, Rogers RS, Bergamo L, Masso J, Black M. A prospective, randomized, comparative study of collagenase and papain-urea for pressure ulcer debridement. Wounds, 2002;14(8):293-301.

10. Pullen R, Popp R, Volkers P, Füsgen I. Prospective randomized double-blind study of the wound-debriding effects of collagenase and fibrinolysin/deoxyribonuclease in pressure ulcers. Age Ageing, 2002;31(2):126-30.

11. AMDA. American Medical Directors Association. Pressure Ulcers in the Long-Term Care Setting Clinical Practice Guideline. Columbia, MD: AMDA; 2008

12. Bergstrom N, Bennett, M.A., Carlson, C.E., et al. Treatment of Pressure Ulcers. Clinical Practice Guideline, No. 15. AHCPR Pub. No. 95-0653. Rockville, MD: U.S. Department of Health and Human Services. Public Health Service, Agency for Healthcare Policy and Research; 1994.

13. Keast DH, Parslow N, Houghton PE, Norton L, Fraser C. Best practice recommendations for the prevention and treatment of pressure ulcers: Update 2006. Adv Skin Wound Care, 2007;20(8):447-60.

14. Wound Ostomy and Continence Nurses Society. Guideline for the Prevention and Management of Pressure Ulcers. Mount Laurel, NJ: WOCNS, 2010.

15. Wounds Australia. Standards for Wound Prevention and Management. Osborne Park, WA: Cambridge Media, 2016.

16. European Pressure Ulcer Advisory Panel, National Pressure Injury Advisory Panel, Pan Pacific Pressure Injury Alliance. Prevention and Treatment of Pressure Ulcers/Injuries: Clinical Practice Guideline. The International Guideline. Haesler E, editor: EPUAP/NPIAP/PPPIA; 2019

17. Kravitz SR, McGuire J, Zinszer K. Management of skin ulcers: understanding the mechanism and selection of enzymatic debriding agents. Adv Skin Wound Care, 2008. Feb;21(2):72-4.

18. Ramundo J, Gray M. Collagenase for enzymatic debridement: a systematic review. J Wound Ostomy Continence Nurs, 2009. NovDec;36(6 Suppl):S4-11.

19. Attinger CE, Janis JE, Steinberg J, Schwartz J, Al-Attar A, Couch K. Clinical approach to wounds: Debridement and wound bed preparation including the use of dressings and wound-healing adjuvants. Plast Reconstr Surg, 2006;117(7 Suppl):72S-109s.
20. Mearns ES, Liang M, Limone BL, Gilligan AM, Miller JD, Schaum KD, Waycaster CR. Economic analysis and budget impact of clostridial collagenase ointment compared with medicinal honey for treatment of pressure ulcers in the US. Clinicoecon Outcomes Res, 2017. 16 Aug;9:485-94.

21. Carter MJ, Gilligan AM, Waycaster CR, Schaum K, Fife CE. Cost effectiveness of adding clostridial collagenase ointment to selective debridement in individuals with stage IV pressure ulcers. J Spinal Cord Med, 2017. 04 Mar;20(3):253-65.

22. Joanna Briggs Institute Levels of Evidence and Grades of Recommendation Working Party. New JBI Grades of Recommendation. Adelaide: Joanna Briggs Institute; 2013.

23. Aromataris E, Munn Z, editors. Joanna Briggs Institute Reviewer's Manual. https://reviewersmanual.joannabriggs.org/ The Joanna Briggs Institute; 2017.

24. The Joanna Briggs Institute Levels of Evidence and Grades of Recommendation Working Party. Supporting Document for the Joanna Briggs Institute Levels of Evidence and Grades of Recommendation. www.joannabriggs.org: The Joanna Briggs Institute; 2014

25. Smith RG. Enzymatic debriding agents: An evaluation of the medical literature. Ostomy Wound Manage, 2008;54(8):16-34.

26. Martin SJ, Corrado OJ, Kay EA. Enzymatic debridement for necrotic wounds. J Wound Care, 1996;5(7):310-1.

27. Carter MJ, Gilligan AM, Waycaster CR, Fife CE. Treating pressure ulcers with clostridial collagenase ointment: Results from the US Wound Registry. Wound Repair Regen, 2016;24(5):904-12.

28. Schultz GS, Sibbald RG, Falanga V, Ayello EA, Dowsett C, Harding K, Romanelli M, Stacey MC, Teot L, Vanscheidt W. Wound bed preparation: A systematic approach to wound management. Wound Repair Regen, 2003;11(2):S1-28.

29. Shi L, Ermis R, Kiedaisch B, Carson D. The effect of various wound dressings on the activity of debriding enzymes. Adv Skin Wound Care, 2010. Oct;23(10):456-62.

\section{Coloplast Biatain Literary Awards}

\section{Wound Practice \& Research, the Australian Journal of Wound Management and Coloplast Australia are pleased to offer three Coloplast Biatain Literary Awards.}

\section{These awards are designed to encourage and reward those who publish their wound care clinical experience. The awards acknowledge excellence of original manuscripts, case presentations and clinical research undertaken within Australasia, both novice and advanced.}

Each winner of the Coloplast Biatain Literary Award receives $\$ 1000$ to be used towards future endeavours in wound management. To enter you must be the first-named author of a manuscript published in Wound Practice \& Research Journal. Manuscripts must relate to a case study, original research or a literature/clinical practice review, authors are preferably members of Wounds Australia.

Judged by the Editorial Board of Wound Practice \& Research annually, one award per category is given based on published articles in the calendar year.

Coloplast manufactures Biatain, Biatain Ag, Biatain Ibu, Biatain Silicone, Biatain Silicone Lite, Biatain Super, Biatain Alginate, Comfeel Plus Transparent and Ulcer dressings which provide integrated solutions in wound healing. Coloplast Wound Care is committed to the development of excellence in wound management practices.

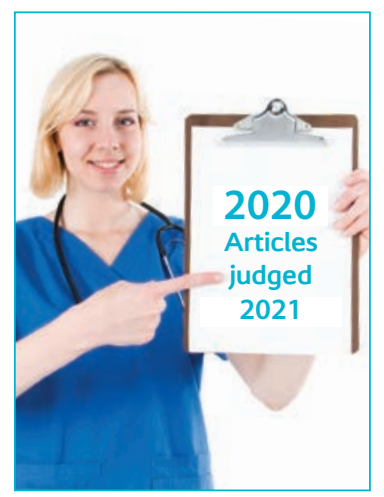

